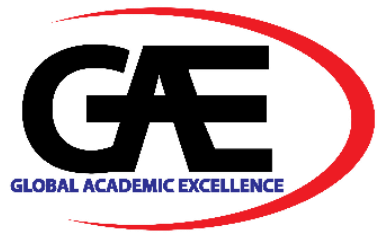

\title{
ONLINE TRUST DEVELOPMENT IN ONLINE SHOPPING
}

\author{
Fatin Farhana Kamis ${ }^{1 *}$, Wan Farha Wan Zulkiffli ${ }^{2}$ \\ 1 Faculty Entrepreneurship and Business, Universiti Malaysia Kelantan (UMK), Malaysia \\ Email: fatinkamis.fk@gmail.com \\ 2 Faculty Entrepreneurship and Business, Universiti Malaysia Kelantan (UMK), Malaysia \\ Email: farha@umk.edu.my \\ * Corresponding Author
}

\section{Article Info:}

Article history:

Received date: 10.06 .2020

Revised date: 24.06 .2020

Accepted date: 09.09.2020

Published date: 15.09 .2020

\section{To cite this document:}

Md. Saad, K., Idris, M. Z., \& Johari, N. R. (2020). Evaluating SMEs Food Packaging Design Characteristic. Journal of Information System and Technology Management, 5 (18), 2632.

DOI: $10.35631 /$ JISTM.518003.

\begin{abstract}
:
Emerging technologies have helped everyone get through their daily tasks and become easier. however, it is still a concern for many people to use technology because they do not know how to trust someone in helping to solve something. In many previous types of research, the focus has been found in the relationship between consumer trust and its antecedents. This article examines the factor that can develop trust among consumers in online shopping. There are 6 factors that are used to test online trust development: reputation, risk, website quality, service quality, business size, and the reference group. The methodology for the study is quantitative and the questionnaire will be distributed through an online survey in line with the ongoing research related to the online. This will be more targeted to online users especially the younger generation who are more likely to use technology.
\end{abstract}

\section{Keywords:}

Online Shopping, Trust, Reputation, Website Quality, Service Quality, Business Size, Risk, Reference Group

\section{Introduction}

The Internet has become an indispensable means of communicating despite being separated from the continent especially in business. But how does one know if the seller is being honest with the customer? Internet users are increasing as the number of clicks on vendors online has also increased significantly. Though the rise of Internet users is increasing, seller sellers fail to attract users to make purchases. Every online retailer has tried to attract customers to make a purchase. But what determines their purchase is through seller behaviour how they create a relationship in the virtual world. they need to establish long-term relationships with consumers 


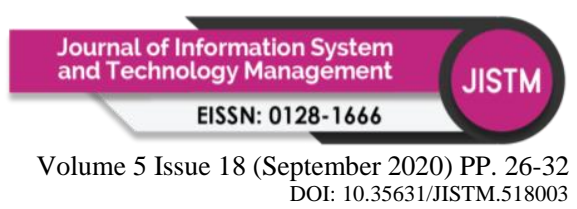

to build consumer confidence and trust in the seller. Research in the field of e-commerce has been widespread but the emphasis on online trust development has not been comprehensive (Bauman \& Bachmann, 2017). The Internet enables organizations to conduct businesses in cyberspace, or connect people worldwide without geographical limitations unlike traditional store and the opportunity has been given to almost everyone. For this reason, consumers become more comfortable with the online business experience because of the convenience and range of product (Saha, 2015)Additionally, browsing an internet for consumer to gather an information before purchase a product can said as a primary factors (Mikalef, Giannakos, \& Pateli, 2013). Despite, offline store allows consumer to touch and feel the products, yet online stores still become consumer choice because of the lowers price offer than in a store (Saha, 2015).

E-commerce is an easy way to shopping for many people preferred as they find it easy and convenient. Several factors make an e-commerce business successful. Some of the research shows that trust, security, privacy and quality of goods are among the main factors that influence consumer behavior. The most important factor in the influence of behavior is trust (Kharel, 2018). Most consumers see online shopping as more risky than traditional purchases that can physically satisfy them by viewing, touching a product before making any purchase (Liat \& Wuan, 2014; Meskaran, Ismail, \& Shanmugam, 2013). That most users do not dare to buy online for fear of being deceived (Juniwati, 2014). Because lack of trust, customer will have doubly to make an online purchase because they will feel insecure. Thus, it difficult to believe others person (online seller) is honest an online store will deliver on its commitments (Wijoseno, 2018). Online shopping becomes a challenge for most consumer, especially traditional consumers. The risks of the online transactions with the objective are tempted to have more intentions to buy online if it has more trust in the seller (Meskaran et al., 2013; Muda, Mohd, \& Hassan, 2016). Therefore, online purchasing can increase a risk in term of delivery delay, information exchange between two parties and lack of trust is the greatest barrier when involved internet transaction (Kim, Xu, \& Koh, 2004).

\section{Literature Review}

\section{Defining Trust}

Trust is a set of behavior and an integral part of all human relationships and belief that the other party will act in ways that depend on another.

- In this situation, requires two actors - trustor and trustee - must exist to develop trust.

- Trust can be caused by many circumstances and it is a sensitive concept

It is also an expectation that others will act in accordance with their commitment, negotiate honestly and not take advantage of the situation despite the opportunity (Thi \& Nga, 2018). This definition of trust is often cited in many other studies and widely recognized.

\section{Online Trust}

Online trust is an Internet users psychological state of risk acceptance based upon the positive expectations of the intentions and behaviors of an online vendor. Online trust is definitely different than traditional trust. It refer to the willingness of the consumer to belief and rely that others party will perform an important action and make consumer vulnerable to the seller (Wijoseno, 2018). Basically, trust can lead to intent of the transaction and seen as an important key belief that creates a positive attitude ( $\mathrm{Lu} \&$ Fan, 2014). In fact, online opinion and 


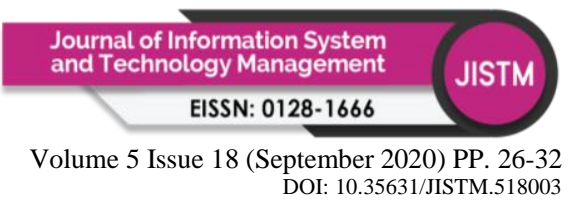

recommendation from another internet user or consumer can lead to trustworthy for future prospect. Positive or negative comments from the previous consumer will affect the consumer trust towards the product and quality. Trust plays a significant role in context online shopping because consumers feeling of trusts towards online seller are important to consider her/his intention. The buyer only depends on the information displayed on the website when making a decision to buy or not because they cannot touch and feel the product. So, every online transaction requires the user to use the internet technology to interact (Kulathunga \& Athapaththu, 2018). Trust is an important factor to create a relationship between seller and buyer in online purchase intention e-commerce (Al-Swidi, Behjati, \& Shahzad, 2012; Meskaran et al., 2013). In e-commerce context, trust is including expectation characteristic of online seller.

Consumer will make purchasing based on their trust level to the product especially salesperson and company (Meskaran et al., 2013). Sellers need to gain trust from consumers from different aspects of online purchases. This is because when shopping, as consumers, they feel at risk. Similarly, consumer uses the internet as a communication tool to submit their private information. the users must feel that their information is protected and not used for other purposes without their permission (Kharel, 2018). Furthermore, they go through the process of choosing a payment method and hope that the website is trusted and secures transactions in an honest manner at the time of purchase. Consumer trust and satisfaction on something is based on a long-term relationship between company and a customer. Basically, customer trust is the most fundamental factor for an online store. Trust in on online sites is a significant determinant in deciding the achievement or failure of any e-commerce activities in the market (Wijoseno, 2018). No physical relationship between consumer and seller in online store will be have some affected by consumer characteristic rather than seller action.

\section{Research Model}

Throughout previous research overview, researcher has realized there are some limitation and created the own research model to analyse the trust development in online shopping. The research model are foundation from trust model in online shopping (Thi \& Nga, 2018). There will have some adjustment include six independent variables: website quality, reference group, risk, reputation, business size and service quality.

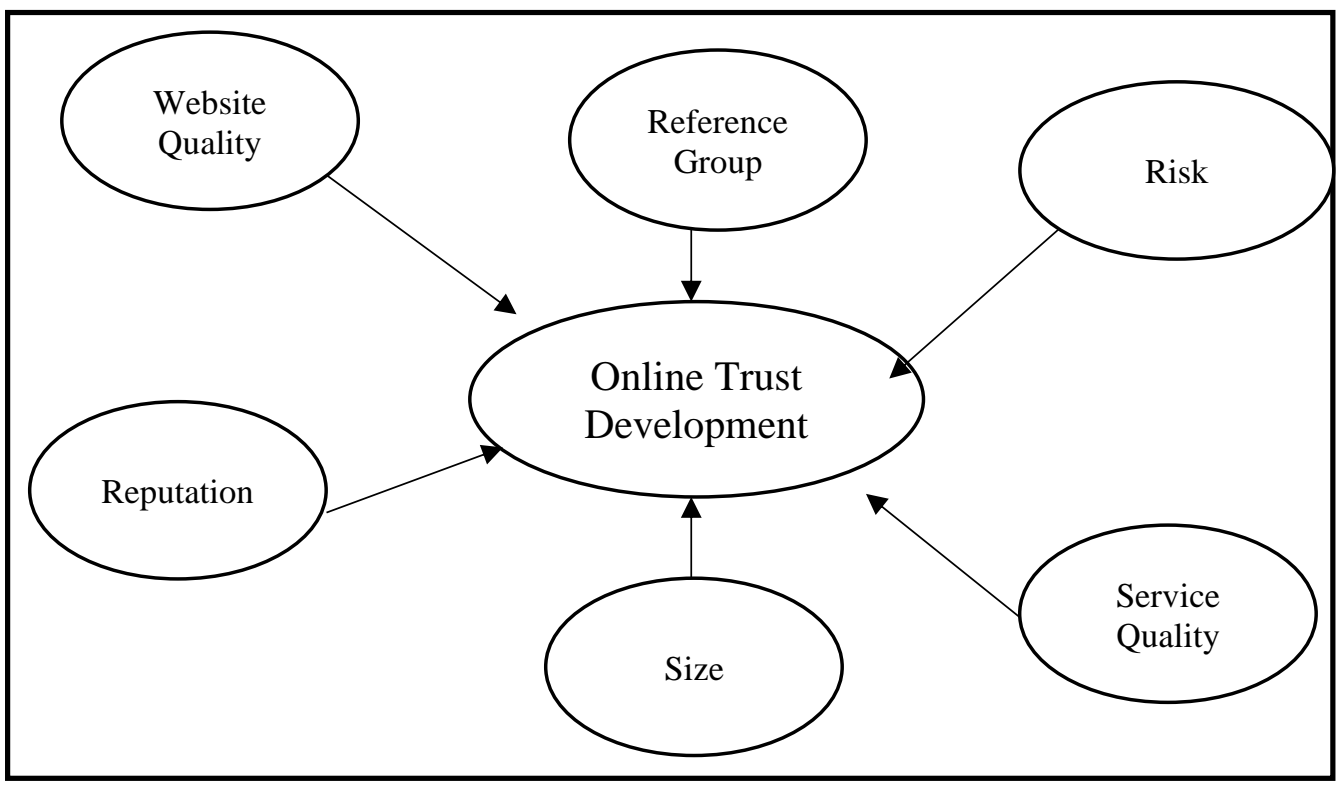

Copyright $\odot$ GLOBAL ACADEMIC EXCELLENCE (M) SDN BHD - All rights reserved 


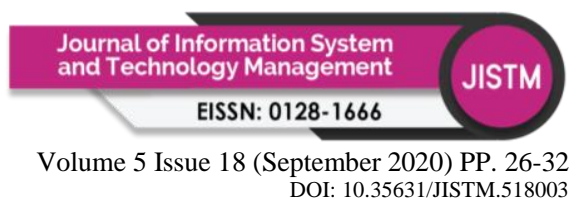

\section{Online Trust Development}

Developing consumer trust on the internet is a major challenge for online sellers and is a topic of growing concern among researchers because the future of trading depends on online consumer trust. It is a major concern for the public to engage in e-commerce because of the many possibilities that will occur in the cyber world, especially when it involves financial and personal information transactions that are transmitted through the internet (Wang \& Emurian, 2005). This development is very important for nowadays because mostly people are preferred to use technology and deal through virtual.

\section{Reputation}

Reputation is the general opinion or belief of an individual or organization. It is a key of success. From reputation will also determine whether someone is honest and trustworthy. In this study, it is defined as to which consumer believes a company or sellers ability, honesty and concern about consumer (Thi \& Nga, 2018). To have a good reputation, the seller must not be focused only on profit but it must balance corporate social responsibility too and it will show a good image for the company (Muda et al., 2016). Thus, online sellers who can build a strong reputation have the advantage of bringing a lot of traffic to their online store. In short, reputation is very important to impress consumer and directly affects shoppers trust.

$\boldsymbol{H}^{\mathbf{1}}$ : Reputation is positively related to consumer trust development in online shopping.

\section{Risk}

Basically, the concept of risk can be classified into various types of risk in the marketing literature such as product risk, privacy risk and financial risk (Ling, Daud, Piew, Keoy, \& Hassan, 2011). Shopper should deal with an unfamiliar seller and faced risk and feel insecure such as submit a piece of personal information and make a financial transaction (Lee, Ahn, Song, \& Ahn, 2018). Although some security mechanisms are already in place, users are still at risk when engaging in transactions in cyberspace. Traditional shopping has a lower risk compared to online purchase and this impedes the readiness of consumers to make online purchases.

$\boldsymbol{H}^{2}$ : Risk is positively related to consumer trust development in online shopping.

\section{Reference Group}

Reference group determine to help other to navigate their ways through the situation of their need. The reference group can be around us whether we know it or not, especially peer certainly can be a negative, but it also can be a positive. When a potential consumer has little or no direct experience with the vendor, the third-party opinion about its trustworthiness can be a major source of information (Muda et al., 2016). Usually testimonial from previous customer can help the potential customer to make a decision in online purchase. Company should prefer sharing knowledge or purchasing experience than advertising products especially in the virtual community (Balakrishnan, Dahnil, \& Yi, 2014). Therefore, it can be assumed that online they depend on each other for seller warranties and online products information. Gen Y spends a lot of time to connecting to their friend and also view a comment from general public and previous purchaser to make a decision (Muda et al., 2016).

$\boldsymbol{H}^{3}$ : Reference group is positively related to consumer trust development in online shopping. 


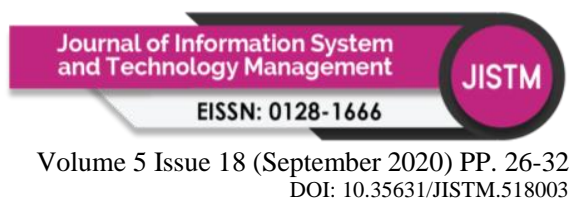

\section{Website Quality}

Website quality will indicate that customers find it easy to find something on the online store website. In addition, a good website can also help customers find information on the website and make a transaction. people are more likely to trust the store's online shopping when they find the website easy to use and beautifully organized. Consumer attitudes towards online retailer will be more positive when the online shop have a higher website quality (Al-Debei, Akroush, \& Ashouri, 2015). buyers' perception of website quality affected can their trust (Lee et al., 2018).

$\boldsymbol{H}^{4}$ : Website Quality is positively related to consumer trust development in online shopping.

\section{Service Quality}

Service quality is intertwined to gain customer trust and build long term relationships with customers by providing the best service. Customers' perceptions of a company's service quality affect trust in online shopping (Mao, 2010). The more good response consumer get from seller, the more attracting for consumer (Prasath \& Yoganathen, 2018). A good service will provide a great return to the online store. this is because, most customers who are satisfied with the service provided will come back for repurchase. Purchase through online consumer has lack of touch and feel the product before purchase. Therefore, the honest information provided to consumer are meaningful to them and consumer sees the online store can be trusted.

$\boldsymbol{H}^{\mathbf{5}}$ : Service Quality is positively related to consumer trust development in online shopping.

\section{Business Size}

Similar to reputation, customers' perceived size of a company plays an important role in forming their trust toward Internet shopping. Larger size of company gives a signed to consumer that the company is successful and have a capability to give what consumers wants even there have a failure they still can handle it well. In addition, companies of larger size are also believed to have ample resources to increase consumer confidence (Mao, 2010)

$\boldsymbol{H}^{\mathbf{6}}$ : Business size is positively related to consumer trust development in online shopping.

\section{Conclusion}

This study demonstrated the factor that can develop trust among consumer in online shopping: reputation, website quality, service quality, risk, reference group, and business size. however, this study has several contributions such as helping sellers to have better understand consumer psychology, and helping sellers learn how to build trust among their customers. Besides that, from this study also seller also can arrange their strategies to grow the business.

\section{Reference}

Al-Debei, M. M., Akroush, M. N., \& Ashouri, M. I. (2015). Consumer attitudes towards online shopping: The effects of trust, perceived benefits, and perceived web quality. Internet Research, 25(5), 707-733. https://doi.org/10.1108/IntR-05-2014-0146

Al-Swidi, A. K., Behjati, S., \& Shahzad, A. (2012). Antecedents of Online Purchasing Intention among MBA Students: The Case of University Utara Malaysia Using the Partial Least Squares Approach. International Journal of Business and Management. https://doi.org/10.5539/ijbm.v7n15p35 


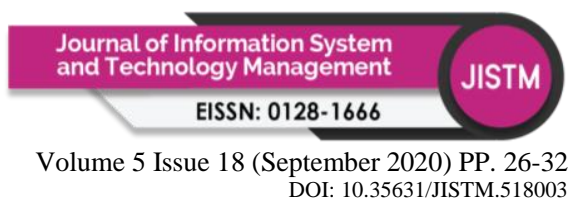

Balakrishnan, B. K. P. D., Dahnil, M. I., \& Yi, W. J. (2014). The Impact of Social Media Marketing Medium toward Purchase Intention and Brand Loyalty among Generation Y. Procedia - Social and Behavioral Sciences, 148, 177-185. https://doi.org/10.1016/j.sbspro.2014.07.032

Bauman, A., \& Bachmann, R. (2017). Online consumer trust: Trends in research. Journal of Technology Management and Innovation, 12(2), 68-79. https://doi.org/10.4067/S071827242017000200008

Juniwati. (2014). Influence of Perceived Usefulness, Ease of Use, Risk on Attitude and Intention to Shop Online. European Journal of Business and ManagementOnline), 6(27), 2222-2839. https://doi.org/ISSN 2222-2839

Kharel, B. (2018). Factors Influencing Online Brand Trust : Evidence from Online Buyers in Kathmandu Valley, 3(1), 47-64.

Kim, H.-W., Xu, Y., \& Koh, J. (2004). A Comparison of Online Trust Building Factors between Potential Customers and Repeat Customers. Journal of the Association for Information Systems, 5(10), 392-420. https://doi.org/10.17705/1jais.00056

Kulathunga, K. M. S. ., \& Athapaththu, J. . (2018). Factors Affecting Online Purchase Intention: A Study Of Sri Lankan Online Customers. International Journal of Scientific \& Technology Research, 7(9), 1-10. Retrieved from https://www.researchgate.net/publication/327953980\%0AFactors

Lee, S. J., Ahn, C., Song, K. M., \& Ahn, H. (2018). Trust and distrust in e-commerce. Sustainability (Switzerland), 10(4). https://doi.org/10.3390/su10041015

Liat, C. B., \& Wuan, Y. S. (2014). Factors Influencing Consumers' Online Purchase Intention: A Study among University Students in Malaysia. International Journal of Liberal Arts and Social Science, 2(8), 121-133. https://doi.org/10.5539/ass.v10n9p18

Ling, K. C., Daud, D. Bin, Piew, T. H., Keoy, K. H., \& Hassan, P. (2011). Perceived Risk, Perceived Technology, Online Trust for the Online Purchase Intention in Malaysia. International Journal of Business and Management, 6(6). https://doi.org/10.5539/ijbm.v6n6p167

Lu, B., \& Fan, W. (2014). Social presence, trust, and social commerce purchase intention: An empirical research. 18th Pacific Asia Conference on Information Systems, PACIS 2014, 56, 225-237. https://doi.org/10.1016/j.chb.2015.11.057

Mao, D. (2010). A Study of Consumer Trust in Internet Shopping And the Moderating Effect of Risk Aversion in Mainland China.

Meskaran, F., Ismail, Z., \& Shanmugam, B. (2013). Online Purchase Intention: Effects of Trust and Security Perception. Australian Journal of Basic and Applied Sciences, 7(6), 307315.

Mikalef, P., Giannakos, M., \& Pateli, A. (2013). Shopping and word-of-mouth intentions on social media. Journal of Theoretical and Applied Electronic Commerce Research, 8(1), 17-34. https://doi.org/10.4067/S0718-18762013000100003

Muda, M., Mohd, R., \& Hassan, S. (2016). Online Purchase Behavior of Generation Y in Malaysia. Procedia Economics and Finance, 37(16), 292-298. https://doi.org/10.1016/S2212-5671(16)30127-7

Prasath, P., \& Yoganathen, A. (2018). Influence of Social Media Marketing On Consumer Behavior in Karachi. International Journal of Scientific and Research Publications (IJSRP), 9(2), p8670. https://doi.org/10.29322/ijsrp.9.02.2019.p8670

Saha, A. (2015). A Study on "The impact of online shopping upon retail trade business." Journal of Business and Management, 74-78. Retrieved from www.iosrjournals.org 
Volume 5 Issue 18 (September 2020) PP. 26-32 DOI: $10.35631 /$ JISTM.518003

Thi, N., \& Nga, P. (2018). Factors affecting on consumers' trust in shopping online for technology and electronic products, 9(11), 1113-1126.

Wang, Y. D., \& Emurian, H. H. (2005). An overview of online trust: Concepts, elements, and implications. Computers in Human Behavior, 21(1), 105-125. https://doi.org/10.1016/j.chb.2003.11.008

Wijoseno, J. (2018). Perceived Factors Influencing Consumer Trust and Its Impact on Online Purchase Intention in Indonesia, (April). https://doi.org/10.21275/8081706 